Paweł Hanczewski

Nicolaus Copernicus University, Poland

ORCID: 0000-0003-4164-6310

e-mail: ph@umk.pl

\title{
George Berkeley: Forging the Irish Nation
}

DOI: http://dx.doi.org/10.12775/RF.2018.042

In the first half of the 18th century two parts of the British Isles could pride themselves on having two men who earned honourable title of 'the patriot' or 'a model patriot'. ${ }^{1}$ These two parts were Scotland and Ireland, and these two men were Andrew Fletcher of Saltoun and Jonathan Swift respectively. Needless to say, they were not the only 'patriots' in their countries. In Scotland there existed a group known as 'patriots', in Ireland 'Protestant patriots', but no other member of any of those groups ever deserved the title of 'the patriot' or 'a model patriot'. One of 'ordinary patriots' was George Berkeley, and this despite his writings on the political and economic situation of Britain and his native Ireland. It has been noted that while some of his works achieved popularity, with his major economic tract, The Querist, going through ten printings in the $18^{\text {th }}$ century, they had little influence on the welfare of his countrymen. ${ }^{2} \mathrm{~Pa}-$ radoxically, the fact that Berkeley did not enjoy the status of 'the patriot'

1 Paul Scott, "Andrew Fletcher, a Pioneer of the European Idea," in The Saltoun Papers: Reflections on Andrew Fletcher, ed. Paul Scott (Edinburgh: Saltire Society, 2003), 13; John Robertson, "Introduction," in Andrew Fletcher Political Works, ed. John Robertson (Cambridge: Cambridge University Press, 1997), XI; Carole Fabricant, "Swift the Irishman," in The Cambridge Companion to Jonathan Swift, ed. Christopher Fox (Cambridge: Cambridge University Press, 2003), 53.

2 Patrick Kelly, "Berkeley's Querist: 'Hints... What Is to Be Done in this Critical State of our Affairs' or Proposals for a Hyperborean Eutopia?," in The Bloomsbury Companion to Berkeley, ed. Bertil Belfrage and Richard Brook, (London: Bloomsbury, 2017), 197; Scott Breuninger, “A Panacea for the Nation: Berkeley's Tar-water and Irish Domestic Development," Etudes irlandaises (2009): 30. 
or 'a model patriot' can be attributed to the quality and importance of his philosophical tracts that drew much more attention from his contemporaries and future generations than his other writings. My point, however, is that one of the main reasons for this, albeit not the only one, lay in Berkeley's concept of patriotism and nation that ran against sectarian divisions and the politics of the time and proved to be too demanding from a moral perspective to gain popular acceptance and to earn him the titles enjoyed by Fletcher or Swift.

The idea of nationhood requires an identification with a community that can be based on political, religious, cultural, social or economic factors, and this idea is often developed in opposition to the concept of 'alien'. Such a concept of nationhood was adopted by Professor Linda Colley in her highly praised book Britons: Forging the Nation 1707-1837. ${ }^{3}$ The main thesis of this monograph is that, after the English-Scottish union of 1707 the various peoples of Britain gradually developed a sense of 'Britishness' that was based, inter alia, on the common commitment to Protestantism, economic interests, career opportunities created by fast growing colonial empire, and on hostility towards the 'other' or the 'alien', in this case catholic and absolutist France that posed serious threat to the protestant and 'free' people of Britain. The book started a hot debate, and despite some critical voices pointing, inter alia, to the neglect of the role of the Catholic majority in Ireland in the process of the formation of the British nation, her book has continued to enjoy the status of one of the most influential historical works published in recent years.

Professor Colley used a general perspective, presenting the formation and development of British identity at large. The process of development of national identity can also be analysed at the micro-scale, and this perspective makes the picture much more complicated, especially in regard to those individuals who played important intellectual and political roles. To start with Andrew Fletcher. He was strong supporter of an independent Kingdom of Scotland, which in his case meant that Scotland should either remain a state fully independent from England or that it should remain a part of a British composite, but not unitary, monarchy. In other words, his concept of Scottish patriotism and nation was rooted in the political idea of a sovereign Scotland. All other issues that, according to Professor Colley, played a decisive role in shaping British identity, were of no importance to him. Fletcher was a Protestant, but he still actively supported the claim of the Roman Catholic Stuarts to the Scottish throne, to the point of being involved in the Jacobite rebellion of 1715 . He was the largest individual subscriber of the Company

3 Linda Colley, Britons: Forging the Nation 1707-1837 (New Haven and London: Yale University Press, 1992). 
of Scotland, that had lost funds in the Darien scheme, and hence he was entitled to the highest compensation from the English Treasury as a part of the treaty securing the Union of 1707. Despite this, Fletcher voted in the Scottish Parliament against the Article 15 of the treaty that settled the question of compensation for losses incurred in the Darien adventure, even though he was a beneficiary of this agreement. He voiced his major point in one of his parliamentary speeches when, criticizing those members who rejected his proposal to strengthen the position of the Scottish parliament, he said: 'he who refuses his consent to them, whatever he may be by birth, cannot be a Scots-man by affection. This will be a true test to distinguish, not whig from tory, Presbyterian from Episcopal, Hanover from St. Germains, not yet a courtier from an out of place; but a proper test to distinguish a friend from an enemy to his country'. ${ }^{4}$

The issue of national identity was even more complicated in the case of Berkeley. He is usually described as 'Anglo-Irish' or as a 'Protestant patriot' ${ }^{\prime}{ }^{5}$ but these are little more than empty names. ${ }^{6}$ In his early Philosophical Commentaries, which he began writing in 1707, Berkeley described himself as Irish: 'We Irish men'. ' In An Essays towards preventing the ruin of Great Britain, published in 1721, Berkeley identified himself with Great Britain and England in particular, writing about 'British worth and honour', 'the old English modesty', and 'our [British] affairs'. ${ }^{8}$ In his major economic work, The Querist, published for the first time in parts between 1735 and 1737, Berkeley underlined the very close links between the elites of Ireland and England, asking finally 'Whether it be not the true Interest of both Nations, to become one People?' (Q 90). ${ }^{9}$ At the same time, however, he wrote about 'our Irish Natives' (Q 19), describing them as 'my Countrymen' (Q 84). He stressed that plans for the improvement of the economic condition of Ireland had to

4 Andrew Fletcher, "Speeches by a member of the Parliament which began at Edinburgh the 6th of May, 1703," in Andrew Fletcher Political Works, ed. John Robertson (Cambridge: Cambridge University Press, 1997), 145.

5 Scott Breuninger, Recovering Bishop Berkeley: Virtue and Society in the Anglo-Irish Context (New York: Palgrave Macmillan, 2010), 9; Thomas Bartlett, Ireland. A History (Cambridge: Cambridge University Press, 2010), 153-158.

6 Joep Leerssen, "Anglo-Irish Patriotism and Its European Context: Notes towards a Reassessment," Eighteenth-Century Ireland 3 (1988): 8.

7 George Berkeley," "Philosophical Commentaries," in The Works of George Berkeley, The Works of George Berkeley Bishop of Cloyne, ed. Arthur Aston Luce and Thomas Jessop (London: Thomas Nelson and Sons, vol. I, 1956), entries 392-394, 47.

8 George Berkeley, "An Essays towards preventing the ruin of Great Britain," in The Works of George Berkeley Bishop of Cloyne, ed. Arthur Aston Luce and Thomas Jessop (London: Thomas Nelson and Sons, vol. VI, 1953), 84.

9 George Berkeley, "The Querist," in The Works of George Berkeley Bishop of Cloyne, ed. Arthur Aston Luce and Thomas Jessop (London: Thomas Nelson and Sons, vol. VI, 1953). References to The Querist are given in the text in the form (Q 000). 
take into account all the inhabitants of the country, regardless of their religion, origins or social status (Q 255). In his later works he identified himself even more strongly with Ireland and Irish nationality. This was reflected not only in a title of one his works, The Irish Patriot; or Queries upon Queries, but also in his repeated calls for common action by both Protestant and Catholic Irishmen to eradicate poverty. Once more he described Ireland as 'our country' and Irish Catholics as his 'countrymen and neighbours', stressing that they were in no way 'inferior to their [Protestant Anglo-Irish] neighbours'.$^{10}$

Berkeley described himself at times as British, English and Irish, and both Britain and Ireland as his country. The only identity he did not accept was that of an 'Irish native', i.e. an Irish Roman Catholic, though at the same time he treated Roman-Catholics as his compatriots. The picture is therefore quite complex.

It is relatively simple to explain Berkeley's double, that is, British and Irish, political identity. In modern Europe nearly all states belonged to the category of 'composite states', that is, states including 'more than one country under the sovereignty of one ruler', ${ }^{11}$ in which the different states retained separate political and legal systems. Under such political circumstances it was possible to have a dual, 'country' and 'state' political identity, and indeed it was quite common in that period. This was characteristic even of Andrew Fletcher who saw Scotland as a part of the British state, though of course this state should be based on a personal, not an incorporating union. It is worth noting that, over the course of time, Berkeley put more and more stress on his Irish rather than British political identity and tried to establish cooperation with Irish Roman Catholics. This can be explained by his exceptional commitment to the well-being of the people of his diocese, regardless of their faith, but it was just merely part of the bigger picture. ${ }^{12}$ This can also be explained by his disillusion with London's policies towards Ireland. These resulted from his conviction that English politicians aimed only at well-being of England neglected or even hindered the economic development of Ireland. In The Querist he empathized that solutions to the economic difficulties of Ireland could only be found in Ireland and they could be solved only

10 George Berkeley, "A Word to the Wise," in The Works of George Berkeley Bishop of Cloyne, ed. Arthur Aston Luce and Thomas Jessop (London: Thomas Nelson and Sons, vol. VI, 1953), 235-237.

11 Helmut Koenigsberger, "Dominium Regale or Dominium Politicum et Regale. Monarchies and Parliaments in Early Modern Europe," in Politicians and virtuosi. Essays in early modern history, ed. Helmut Koenigsberger (London: Hambledon Press, 1986), 12.

12 David Berman, George Berkeley. Idealism and the man (Oxford: Clarendon Press, 1994), 167. 
by the Irish (Q 80, 135, 137). ${ }^{13}$ Such a disillusionment was not limited only to Berkeley. The 'model patriot' Jonathan Swift, who strongly supported idea of Anglo-Irish political integration, ${ }^{14}$ after the English-Scottish union of 1707 became more and more critical of the British treatment of Ireland. He expressed such views in a series of pamphlets and books, including some of his best known works, such as Gulliver's Travels and The Drapier's Letters. To be sure, Berkeley retained his sense of British political identity, underlying his belief that, while Ireland's problems can be solved only by the Irish, Ireland must nevertheless remain a part of the British state. He urged the Roman Catholic clergy in Ireland to cooperate with 'the public spirit of the legislature, and men in power' for the common good of all the inhabitants of Ireland, ${ }^{15}$ and, during the Jacobite rebellion of 1745, he advised Irish Roman Catholics not to take part in the rebellion, stressing the mutual dependence between them and Irish Protestants. ${ }^{16}$

It is more difficult to explain Berkeley's national identity. He crossed all existing lines, describing himself as British, English and Irish. Leaving aside his 'British' national identity and its relationship to an 'English' identity, there remains the question of how he managed to combine English and Irish national identities at the time when strife between the English and the Irish was markedly clear not only in political, social and cultural terms, but also in many aspects of daily life. Berkeley knew these divisions all too well, and he openly admitted that he was not a 'native Irish', belonging instead to 'the upper Part of this People' that was 'truly English, by Blood, Language, Religion, Manners, Inclination and Interest' (Q 91). Despite this he insisted on numerous occasions that Irish Roman Catholics were his countrymen, though, as with some other Irish Protestants, he could leave them on the margins of society.

Berkeley's idea of the Irish nation as being composed of Protestants and Roman-Catholics was loosely related to a person's place of birth. As we can observe, Andrew Fletcher made a sharp distinction between a Scots-man 'by birth' and a Scots-man 'by affection'. Berkeley on the other hand said that 'a native [rather] than a foreigner...has a better chance for being patriots', ${ }^{17}$ but this was the only reference of this

13 Kelly, "Berkeley's Querist," 200.

14 Colin Kidd, "Integration: Patriotism and Nationalism," in A Companion to Eighteenth-Century Britain, ed. Harry Dickinson, (Oxford: Blackwell, 2002), 370.

15 Berkeley, "A Word," 245.

16 George Berkeley, "A Letter to the Roman Catholics of the Diocese of Cloyne," in The Works of George Berkeley Bishop of Cloyne, ed. Arthur Aston Luce and Thomas Jessop (London: Thomas Nelson and Sons, vol. VI, 1953), 229-230.

17 George Berkeley, "Maxims concerning Patriotism," in The Works of George Berkeley Bishop of Cloyne, ed. Arthur Aston Luce and Thomas Jessop (London: Thomas Nelson and Sons, vol. VI, 1953), 253. 
kind he made. He put much greater stress on the other characteristics of 'a true' or 'a real patriot'. The key to Fletcher's and Berkeley's thinking was hidden under the word 'affection', though they understood its meaning in different ways. Fletcher believed that a Scots-man by 'affection' equaled a person who supported his proposal to strengthen the position of the Scottish parliament that eventually aimed at safeguarding Scotland's independence from England. Berkeley believed that 'affections' were about a common Christian religion, an idea he expressed in the following sentence addressed to Irish Roman Catholics: 'I consider you as my countrymen, as fellow-subjects, as professing belief in the same Christ' ${ }^{18}$ He put forward a concept of what he called 'a real' or 'a true patriotism', and what I would like to call 'Christian patriotism' based not on any commitment to a particular Christian denomination, or political views, economic interests, social status or cultural ties, but on the Christian religion. Berkeley developed this concept in some detail in one of his last works, Maxims concerning Patriotism. Despite its brevity, Maxims is among Berkley's most important non-philosophical works. Published for the first time in 1750, a few years before Berkeley's death, it was the end result of the gradual development of his political and social ideas, especially of his changing attitude towards the Catholic majority. In some of his earlier writings, including the first edition of The Querist, he formulated strongly anti-Catholic opinions, seeing Catholics purely in economic terms. ${ }^{19}$ From the early 1740 s, however, he gradually began to change his views, seeing Catholics more and more as his compatriots. This found its reflection in his controversial work Siris published in $1744,^{20}$ in a change from the term 'papists' to that of 'Roman Catholics' in The Querist after 1745, and in the works he addressed to Irish Roman Catholics. ${ }^{21}$

In Maxims Berkeley presented the definition of 'a patriot' as 'one who heartily wisheth the public prosperity, and doth not only wish, but also study and endeavour to promote it' and also as one who 'aims at his private good in the public', ${ }^{22}$ shares some important elements with civic humanism, by stressing the importance of the common good and active citizenship. ${ }^{23}$ For Berkeley, however, these characteristics were not the

18 Berkeley, "A Word," 248.

19 Kelly, “Berkeley's Querist," 202.

20 Breuninger, "A Panacea," 37.

21 Breuninger, Recovering, 154; Kelly, “Berkeley's Querist," 208-209.

22 Berkeley, "Maxims," 254.

23 John Pocock, The Machiavellian Moment. Florentine Political Thought and the Atlantic Republican Tradition (Princeton: Princeton University Press, 1975), 156-218; John Pocock, "Civic Humanism and its Role in Anglo-American Thought," in Politics, Language and Time. Essays on political thought and history, ed. John Pocock (London: Methuen, 1972), 80-103. 
source of 'a true patriotism', but were forms of its expression. Political activity did not automatically equal patriotism because there always remained a question about one's motives. Some people entered the world of politics to seek their own interests only and hence in his opinion they were not patriots. Berkeley made this point very clear: 'A man whose passion for money runs high bids fair for being no patriot. And he likewise whose appetite is keen for power'. On the other hand, some people remained politically inactive but this did not make them non-patriotic either. 'A true patriotism' found its original source in faith in God and without such a faith one could not be 'a true' or 'a real patriot'. Berkeley formulated this rule indirectly rather than directly, stating: 'A man who hath no sense of God or conscience: would you make such a one guardian to your child? If not, why guardian to the state?', and 'To be a real patriot, a man must consider his countrymen as God's creatures...' . ${ }^{24}$

While 'a true patriotism' was based on faith in God, it found its expression in Christian moral teaching. Besides searching for the common good, 'a true patriot' was honest, selfless, sober, generous, open-minded, guided by 'an inward sense of duty and conscience', rejected violence, refrained from all kinds of vices such as drinking and gambling, and was not greedy for money or power..$^{25}$ The close link between high moral standards on the one hand and patriotism on the other can be seen as typical in a time when there was still a strong belief in the connection between moral practice and the world of politics, but this emphasizes that these features belong to the world of Christian values. Explaining the meaning of patriotism through Christian moral teaching had serious consequences. Berkeley's patriotism was practical and concentrated on relations between individuals, not on theoretical speculations. His guide in this respect were the words from the First Epistle of John: 'for he who doesn't love his brother whom he has seen, how can he love God whom he has not seen?'. ${ }^{26}$ As Berkeley put it: 'A sullen, churlish man, who loves nobody, will hardly love his country'. ${ }^{27}$ 'A true patriotism' was not an abstract idea that could be understood only by the educated elite. Because of its practical dimension, patriotism could be understood by everybody, regardless of religious or political views, social origins or status, economic situation or level of education. This allowed Berkeley to bridge the gap between various Christian denominations in Ireland. Irish Roman Catholics were not a threat to Irish patriotism; indeed, they were as good true Irish patriots as Irish Protestants. 'A true patriotism' recognized the common elements of all Christians; it did not seek those

24 Berkeley, "Maxims," 253.

25 Berkeley, "Maxims," 254.

261 John 4:20.

27 Berkeley, "Maxims," 253. 
elements that differentiated between the rival denominations. Nor did it emphasize other differences, whether political, economic, social or cultural. Berkeley perceived a nation as an entity, not as various groups or classes competing with each other for power or wealth. 'A true patriotism' was much more inclusive than exclusive. It embraced people of all classes, because even the humblest person could contribute, through his or her work and by obedience Christian principles, to the development of the national community. The only people who could be 'expelled like Drones out of a well governed State' were those, who 'employ neither Heads nor Hands for the common Benefit' (Q 3). This observation applied to Protestants and Roman Catholics, rich and poor alike: 'Whether a Woman of Fashion ought not to be declar'd a public Enemy?' (Q 141) Because 'a true patriotism' found its source in Christianity, it was not a construct of the ruling elite, nor were nations the products of particular political, social, economic or cultural circumstances. 'A true patriotism' was a gift from God, and it required knowledge of basic Christian principles and their application in daily life as an individual and as a member of community. Paraphrasing words from the Epistle of James 'A true patriotism without deeds is dead.' 'A true patriotism' was also practical in the sense that it sought a safe and prosperous life for the largest possible number of people. Its aim was not to establish the Kingdom of God on Earth. Its aim was much more prosaic, and it could be achieved only by securing the safety and prosperity of the whole community: 'The patriot aims at his private good in the public... [He] considers himself as part of a whole'.$^{28}$ 'A true patriotism' was not created in opposition to the 'alien' nor did it aim at its destruction. 'A true patriotism' was of a universal character, it applied to the Irish, English or Scots alike. In fact, it applied to any people that accepted the Christian religion and its moral principles. It is worth stressing that the title of the pamphlet was Maxims concerning Patriotism, not Maxims concerning Irish Patriotism. The pamphlet The Irish Patriot concentrated on the establishment of a national bank in Ireland, not on 'patriotism' as such. Consequently, 'a true patriotism' was not created against nor did it aim at the 'alien'; indeed, 'a true patriotism' excluded the concept of the 'alien', when understood as those who belonged to different Christian denominations or to different nations. The threat to 'a true patriotism' did not come from foreign nations or powers, its only source was freethinkers, i.e. people who questioned faith in God and Christian moral teachings.

Finding the origins of 'a true patriotism' in faith in God, emphasizing the importance of Christian moral teaching and seeing the only threat to 'a true patriotism' as coming from freethinkers, combined to form a link between the Maxims, where he presented his views in their

28 Berkeley, “Maxims,” 254. 
most synthetic form, and Berkeley's other writings. His concept of 'a true patriotism' should be considered in a wider context, and as one of the battlegrounds between Berkeley and the freethinkers, towards whom Berkely was very hostile. ${ }^{29}$ His concept of 'a true patriotism' was a part of the central issue present in his political and economic works. These works addressed the current situation of both Britain and Ireland, but the main issue did not concern the economic effects of the South Sea Bubble or the creation of a national bank in Ireland. These were important, but short-term and largely technical issues, and, while reflecting deep-rooted problems, they were not their original cause. By far the most significant issue concerned the foundations on which states and societies should be based. Berkeley's answer was quite simple - the only solid foundation was the Christian religion: 'it [is] impossible that a nation should thrive and flourish without virtue, or that virtue should subsist without conscience, or conscience without religion'. ${ }^{30}$ Unfortunately, as Berkeley often complained, there was a growing number of those who questioned the existence of God and Christian moral teaching, opting instead for societies based on foundations that did not find their source in Christianity. What was worse, they were gradually gaining influence over the public, and this had serious consequences, not only in spiritual or intellectual, but also in practical terms. ${ }^{31}$ Berkeley believed that there existed a strong and direct link between human reasoning and human life. Difficulties that people experienced in all aspects of public life were not God send, rather difficulties resulted from their thinking. As he put it in reference to the economic condition of Ireland: 'whether our real Defect be not a wrong Way of Thinking?' (Q 48). Thinking could be based either on faith in God and Christian moral teaching or, as freethinkers claimed, it could be based on the rejection of both the faith and the teaching. The latter stance, in Berkeley's opinion, could have catastrophic consequences. In the economic life it found its expression in greed, selfishness, the seeking profits at the expense of others, and the achievement of a luxurious lifestyle for a few. On a theoretical level, Berkeley criticized such an attitude in Dialogues 2 of Alciphron, where he attacked Bernard Mandeville's moral and economic views as expressed in The Fable of the Bees, especially his concept that without private vices there could exist no public benefits. ${ }^{32}$ On a more practical level, vices led to a series of economic problems faced both by Britain and Ireland. In Berkeley's view, the South Sea Bubble was caused by a desire for

29 Berman, George Berkeley, 75.

30 Berkeley, "An Essay", 69.

31 Berkeley, "An Essay", 69-70.

32 George Berkeley, "Alciphron; or, the Minute Philosopher," in The Works of George Berkeley, ed. Alexander Fraser (Oxford: Clarendon Press, vol. II, 1901), 69-79. 
wealth based on financial speculations rather than 'the old honest methods of industry', and this desire found its original source in the rejection of 'a sense of public spirit', a virtue that sprang from faith in God. ${ }^{33}$ The economic problems of Ireland were caused to a large extent by rich and privileged Irish people who tried to imitate English elites, and weakened the country through expensive consumption and the neglecting the economic development of the country. They were partly responsible for the miserable condition of the Irish poor (Q 17, 49, 57, 58, 99, 102, 144, 145, $147,149,150,153,155,157)$. The selfishness of an elite minority of the population, stemming from vanity and a total disregard for others, resulted in dire poverty for millions, denying them and their children any prospect of a better life: 'Whether the Vanity and Luxury of a few ought to stand in Competition with the Interest of a Nation?' (Q 167).

With regard to patriotism, the consequences of detaching it from Christian moral teaching could be equally catastrophic. Patriotism would become an empty name. Every person, regardless of his or her lifestyle, could call himself or herself 'a patriot'. A gambler, a cheat, a drunkard, a bully, a scrooge, a thief of public money, to name just a few of the people who Berkeley numbered among 'no true patriots', could claim the opposite: 'I have no opinion of your bumper patriots. Some eat, some drink, some quarrel, for their country. MODERN PATRIOTISM!'. ${ }^{34}$ The term 'patriotism' would be used, and in Berkeley's opinion it was already the case, to justify political actions that aimed at the pursuit of selfish interests at the expense of a nation: 'The fawning courtier and the surly squire often mean the same thing, each his own interest' ${ }^{\prime} .{ }^{35}$ Instead of being one of the binds uniting society, 'patriotism' would become another weapon in political, religious and economic rivalry between individuals and between various socio-economic groups. There was also a question about the consequences of such a 'patriotism' in a wider perspective. If 'patriotism' caused divisions within a society, what effects would it have on relations between different nations and states? 'Patriotism' without Christianity would also be deprived of its social role. One of the aims of 'a true patriotism' was the promotion of social solidarity through the subjection of the interests of rich and privileged to the interests of the national community composed of people of all ranks. As Berkeley wrote: 'A patriot would hardly wish there was no contrast in the State' ${ }^{36}$ To be sure, 'a true patriotism' was not seen by Berkeley as a vehicle for political change. He did not call for the removal of social or political barriers $(Q$ 119), and in his ideal society there existed a clear division between the

\footnotetext{
33 Berkeley, "An Essay,” 71, 78-79.

34 Berkeley, "Maxims," 254.

35 Berkeley, "Maxims," 255.

36 Berkeley, "Maxims," 255.
} 
'lower' and the 'upper' classes: 'Whether it is possible a State should not thrive, whereof the lower Part were industrious and the upper wise?' ( $Q$ $192,201)$. What he feared was that without Christian moral teaching 'patriotism' would be used to provide justification for the opulent lifestyle of the rich and privileged, creating even more divisions and conflicts. It would lead to the atomization of society in which every individual would consider himself or herself not as a 'part of a whole', but 'as the whole'. ${ }^{37}$ Berkeley perceived such a 'patriotism' and its consequences with horror, because it was based on human vices and it approved their existence. This was 'patriotism' of freethinkers, and their triumph would be a disaster for all the people. In Dialogues 1 of Alciphron Berkeley pointed out that the atheists, who attacked Christian teaching, had 'diminished all the most valuable things, the thoughts, views and hopes of men', degrading human nature to 'the narrow low standard of animal life' ${ }^{38}$ If so, what kind of society and state would they create? Would it be possible to achieve any progress towards economic, political or social advance? As Berkeley inquired: 'Whether in any Order a good Building can be made of bad Materials? Or whether any Form of Government can make a happy State out of bad Individuals?' (Q 203). A society and state without Christianity would be a recipe for disaster. 'Patriotism' without Christian teaching would answer the desires of a few, sentencing all the others to a life of poverty and despair. From this perspective the opinion of one historian that the 'morality of a nation determined its overall health', ${ }^{39}$ does not go far enough. Morality based on Christian teaching or a lack of morality determined the entire character of any nation.

Berkeley's remarks on the relationship between Christianity on the one hand and society and state on the other, as well as his insistence on the importance of public spirit, allow to see his idea of 'a true patriotism' in the context of a debate that took place in the British Isles in the early and middle decades of the $18^{\text {th }}$ century. This debate was conducted by the so-called 'Patriots' of whom the most influential during Berkeley's lifetime was Henry St. John, first Viscount Bolingbroke, who concentrated on safeguarding the liberties recovered in the Glorious Revolution and on such questions as whether civil liberty was a matter more of constitutional or of moral order. ${ }^{40}$ This debate was a response to the general condition of the British Isles after 1688, and also to the fast changing situation in the early $18^{\text {th }}$ century, especially the rise of the British fiscal-

37 Berkeley, "Maxims," 254.

38 Berkeley, "Alciphron," 49.

39 Breuninger, Recovering, 156.

40 Harry Dickinson, Bolingbroke (London: Constable, 1970), 184-211, 247-276. 
military state and powerful financial community, ${ }_{1}^{41}$ of which one of the best examples of their dangers was the South Sea Bubble, and new ideas put forward by such thinkers as John Locke, Mandeville and Anthony Ashley Cooper, the third Earl of Shaftesbury. While Berkeley's influence on the moral thinking of such important figures as Edmund Burke has been noticed ${ }^{42}$ there is still some room for research on his contribution to important political debates in Britain.

Berkeley lost the battle over patriotism, and, from a wider perspective, over the concept of the Irish nation. The idea of nationhood that prevailed was the one described by Professor Colley. Faith in God and Christian moral teaching did not become the foundation of patriotism, in the Irish nation or any other nation in the world. In the case of the British nation a sense of belonging to one Christian denomination was used as one of binding ties and as an important element in developing hostility towards the 'alien', i.e. members of another Christian church and another nation. This had nothing in common with Berkeley's concept of patriotism.

Berkeley lost the battle over patriotism also in that that he was not regarded by the majority of his contemporaries as 'a true patriot'. The only exemption was those members of the Roman Catholic clergy in Ireland who welcomed his proposals included in $A$ Word to the Wise. ${ }^{43}$ Nor was he remembered by later generations, such that I have found just one article where he was named 'a great patriot', ${ }^{4}$ as an important figure in the long-lasting discussion over Irish patriotism and the Irish nation. To a certain degree Berkeley's concept of patriotism was utopian. It required very high moral standards and the willingness to live up to them by the majority of the people. Because of its Christian foundations and universal character, his concept of patriotism downplayed the differences between various nations. This could be seen as a threat to the very existence of the Irish nation in the longer perspective. It was a relatively small nation, dominated in many ways by a bigger, stronger and aggressive neighbour. Downplaying national differences and stressing common values could be the first step towards dissolution of the Irish nation into an English or British one. It is much easier to build a national

41 John Brewer, The Sinews of Power: War, Money and the English state, 1688-1783 (London: Unwin, 1989), 250.

42 Richard Bourke, Empire and Revolution: The Political Life of Edmund Burke (Princeton: Princeton University Press, 2015), 18, 72, 119, 123.

43 "Letter from the Roman Catholic Clergy of the Diocese of Dublin," in The Works of George Berkeley Bishop of Cloyne, ed. Arthur Luce and Thomas Jessop (London: Thomas Nelson and Sons, vol. VI, 1953), 230.

44 Graham Conroy, "George Berkeley and the Jacobite Heresy: Some Comments on Irish Augustan Politics," Albion: A Quarterly Journal Concerned with British Studies vol. 3 no. 2 (Summer, 1971): 85. 
identity on the commitment to a single religion, economic interests, career opportunities and hostility towards the 'alien'. It is our duty, however, to remember that good Bishop Berkeley provided an alternative, even if somewhat utopian, concept of patriotism and the Irish nation compared to the concept that eventually prevailed and that far too often degenerated into xenophobia, being one of the main causes of bloody conflicts, including conflicts in Ireland. There is therefore something of value in Christian moral teaching.

\section{Bibliography}

Bartlett, Thomas. Ireland. A History. Cambridge: Cambridge University Press, 2010.

Berkeley, George. "A Letter to the Roman Catholics of the Diocese of Cloyne." In The Works of George Berkeley Bishop of Cloyne, edited by Arthur Aston Luce and Thomas Jessop, 229-230. London: Thomas Nelson and Sons, vol. VI, 1953.

Berkeley, George. "A Word to the Wise." In The Works of George Berkeley, The Works of George Berkeley Bishop of Cloyne, edited by Arthur Aston Luce and Thomas Jessop, 235-249. London: Thomas Nelson and Sons, vol. VI, 1953.

Berkeley, George. "Alciphron; or, the Minute Philosopher." In The Works of George Berkeley, edited by Alexander Fraser, 26-368. Oxford: Clarendon Press, vol. II, 1901.

Berkeley, George. "An Essays towards preventing the ruin of Great Britain." In The Works of George Berkeley, The Works of George Berkeley Bishop of Cloyne, edited by Arthur Aston Luce and Thomas Jessop, 69-85. London: Thomas Nelson and Sons, vol. VI, 1953.

Berkeley, George. "Maxims concerning Patriotism." In The Works of George Berkeley, The Works of George Berkeley Bishop of Cloyne, edited by Arthur Aston Luce and Thomas Jessop, 253-255. London: Thomas Nelson and Sons, vol. VI, 1953.

Berkeley, George. "Philosophical Commentaries." In The Works of George Berkeley, The Works of George Berkeley Bishop of Cloyne, edited by Arthur Aston Luce and Thomas Jessop, 7-139. London: Thomas Nelson and Sons, vol. I, 1948.

Berman, David. George Berkeley. Idealism and the man. Oxford: Clarendon Press, 1994.

Bourke, Richard. Empire and Revolution: The Political Life of Edmund Burke. Princeton: Princeton University Press, 2015.

Breuninger, Scott. "A Panacea for the Nation: Berkeley's Tar-water and Irish Domestic Development." Etudes irlandaises (2009): 29-41.

Breuninger, Scott. Recovering Bishop Berkeley: Virtue and Society in the Anglo-Irish Context. New York: Palgrave Macmillan, 2010. 
Brewer, John. The Sinews of Power: War, Money and the English state, 16881783. London: Unwin, 1989.

Colley, Linda. Britons: Forging the Nation 1707-1837. New Haven and London: Yale University Press, 1992.

Conroy, Graham. "George Berkeley and the Jacobite Heresy: Some Comments on Irish Augustan Politics." Albion: A Quarterly Journal Concerned with British Studies vol. 3 no. 2 (Summer, 1971): 82-91.

Dickinson, Harry. Bolingbroke. London: Constable, 1970.

Fabricant, Carole. "Swift the Irishman." In The Cambridge Companion to Jonathan Swift, edited by Christopher Fox, 48-72. Cambridge: University Press, 2003.

Fletcher, Andrew. "Speeches by a member of the Parliament which began at Edinburgh the 6th of May, 1703." In Andrew Fletcher Political Works, edited by John Robertson, 129-173. Cambridge: Cambridge University Press, 1997.

Kelly, Patrick. "Berkeley's Querist: 'Hints... What Is to Be Done in this Critical State of our Affairs' or Proposals for a Hyperborean Eutopia?." In The Bloomsbury Companion to Berkeley, edited by Bertil Belfrage and Richard Brook, 196-215. London: Bloomsbury, 2017.

Kidd, Colin. "Integration: Patriotism and Nationalism." In A Companion to Eighteenth-Century Britain, edited by Harry Dickinson, 369-380. Oxford: Blackwell, 2002.

Koenigsberger, Helmut. "Dominium Regale or Dominium Politicum et Regale. Monarchies and Parliaments in Early Modern Europe." In Politicians and virtuosi. Essays in early modern history, edited by Helmut Koenigsberger, 1-25. London: Hambledon Press, 1986.

Leerssen, Joep. "Anglo-Irish Patriotism and Its European Context: Notes towards a Reassessment." Eighteenth-Century Ireland 3 (1988): 7-24.

Pocock, John. "Civic Humanism and its Role in Anglo-American Thought." In Politics, Language and Time. Essays on political thought and history, edited by John Pocock, 80-103. London: Methuen, 1972.

Pocock, John. The Machiavellian Moment. Florentine Political Thought and the Atlantic Republican Tradition. Princeton: Princeton University Press, 1975.

Robertson, John. "Introduction." In Andrew Fletcher Political Works, edited by John Robertson, ix-xxx. Cambridge: Cambridge University Press, 1997.

Scott, Paul. "Andrew Fletcher, a Pioneer of the European Idea." In The Saltoun Papers: Reflections on Andrew Fletcher, edited by Paul Scott, 13-19. Edinburgh: Saltire Society, 2003.

\section{Summary}

In his political and economic writings George Berkeley presented a concept of 'true patriotism'. The concept was not based on political views, economic interests, social status, cultural ties or on any commitment to a particular Christian denomination. 'A true patriotism' was not created in opposition to the 'alien' 
nor did it aim at its destruction. 'A true patriotism' was of a universal character, it applied to the Irish, English or Scots alike. In fact, it applied to any people that accepted the Christian religion and its moral principles. Berkeley perceived a nation as an entity, not as various groups or classes competing with each other for power or wealth. 'A true patriotism' was a gift from God and it was also practi$\mathrm{cal}$ in the sense that it sought a safe and prosperous life for the largest possible number of people. Berkeley's concept of 'a true patriotism' should be considered in a wider context, and as one of the battlegrounds between Berkeley and freethinkers. Berkeley provided an alternative, even if somewhat utopian, concept of patriotism and the Irish nation compared to the concept that eventually prevailed and that far too often degenerated into xenophobia, being one of the main causes of bloody conflicts, including conflicts in Ireland.

Keywords: Berkeley, Ireland, nation, Christianity

\section{Streszczenie}

\section{George Berkeley: wykuwając naród Irlandii}

W swoich pracach politycznych i ekonomicznych George Berkeley przedstawił oryginalną koncepcję "prawdziwego patriotyzmu”. Nie była ona powiązana z poglądami politycznymi, kwestiami ekonomicznymi, pozycją społeczna, związkami kulturowymi czy przynależnością do określonego odłamu chrześcijaństwa. Koncepcja nie powstała w opozycji wobec „obcego”. „Prawdziwy patriotyzm" miał uniwersalny charakter i dotyczył każdej osoby, która przyjmowała zasady chrześcijaństwa, nie czyniąc tym samym różnicy między Irlandczykami, Anglikami i Szkotami. Berkeley widział naród jako całość, nie jako grupy bądź klasy rywalizujące o władzę i bogactwo. „Prawdziwy patriotyzm” był darem od Boga i miał bardzo praktyczne cele, dążąc do zapewnienia bezpiecznego i dostatniego życia dla jak największej liczby ludzi. Z szerszej perspektywy, koncepcja Berkeley’a stanowiła część jego debaty z deistami i ateistami, których obdarzał wspólnym mianem „wolnomyślicieli”. Berkeley przedstawił alternatywną i równocześnie utopijną wizję patriotyzmu i narodu irlandzkiego, w stosunku do wizji, która ostatecznie zwyciężyła. Jednak zwycięska wizja bardzo często prowadziła do ksenofobii, będąc jedną z głównych przyczyn krwawych konfliktów toczących Irlandię.

Słowa kluczowe: Berkeley, Irlandia, naród, chrześcijaństwo 